University of Nebraska - Lincoln

DigitalCommons@University of Nebraska - Lincoln

$11-2019$

\title{
Crustal Architecture of the Northwestern and Central Gulf of Mexico from Integrated Geophysical Analysis
}

Irina Filina

University of Nebraska-Lincoln, ifilina2@unl.edu

Follow this and additional works at: https://digitalcommons.unl.edu/geosciencefacpub

Part of the Earth Sciences Commons

Filina, Irina, "Crustal Architecture of the Northwestern and Central Gulf of Mexico from Integrated Geophysical Analysis" (2019). Papers in the Earth and Atmospheric Sciences. 677.

https://digitalcommons.unl.edu/geosciencefacpub/677

This Article is brought to you for free and open access by the Earth and Atmospheric Sciences, Department of at DigitalCommons@University of Nebraska - Lincoln. It has been accepted for inclusion in Papers in the Earth and Atmospheric Sciences by an authorized administrator of DigitalCommons@University of Nebraska - Lincoln. 
Published in Interpretation 7:4 (November 2019), pp. T899-T910; doi: 10.1190/INT-2018-0258.1. Copyright (C) 2019 Society of Exploration Geophysicists and American Association of Petroleum Geologists. Used by permission.

Submitted December 31, 2018; revised April 10, 2019; published ahead of production August 18, 2019; published online October 15, 2019.

\title{
Crustal Architecture of the Northwestern and Central Gulf of Mexico from Integrated Geophysical Analysis
}

\author{
Irina Filina \\ Department of Earth and Atmospheric Sciences, University of Nebraska-Lincoln, Lincoln, Nebraska, USA \\ Corresponding author - Irina Filina, email ifilina2@unl.edu
}

\begin{abstract}
The tectonic history of the Gulf of Mexico (GOM) is a subject for ongoing debate. The nature of the crust in the northwestern and central parts of the basin remains poorly understood. Joined interpretation of two 2D seismic cross sections - GUMBO1 and GUMBO2 - with potential fields (gravity and magnetics) constrained with available well data allows testing various hypotheses about the subsurface structures and crustal architecture in the study area. In the northwestern GOM, two contradicting hypotheses about the nature of the crust were tested-exhumed mantle versus a thinned and intruded continental crust resulted from magma-rich rifting. The nature of the crust was also investigated in the central GOM, where the disagreement in the location of the ocean-continent boundary (OCB) from various published tectonic models reaches $140 \mathrm{~km}(87 \mathrm{mi})$. The results suggest that the crust in the study area is stretched continental with multiple magmatic additions represented by dense and highly magnetic bodies with fast seismic velocities, presumably introduced during the magma-assisted rifting of the GOM. The contact between oceanic and continental domains, i.e., the $\mathrm{OCB}$, is interpreted to be near the Sigsbee Escarpment for both modeled lines. The analysis does not support the presence of thick presalt sediments in the study area. This result questions the currently accepted tectonic reconstructions of the GOM as thick presalt deposits are imaged confidently by various seismic surveys along the western Yucatan margin, which is believed to be a conjugate for the study area. This apparent mismatch in distribution of the presalt sediments requires further investigation.
\end{abstract}




\section{Introduction}

Many tectonic models have been developed that describe the opening of the Gulf of Mexico (GOM) basin, e.g., Pindell and Kennan (2001), Bird et al. (2005), Mickus et al. (2009), Kneller and Johnson (2011), Hudec et al. (2013), Van Avendonk et al. (2015), Nguyen and Mann (2016), and Lundin (2017). The present-day consensus implies that the GOM initiated as a continental rift in the Triassic, followed by a Late Jurassic-Early Cretaceous seafloor spreading event, during which the Yucatan crustal block moved away in a counterclockwise manner from North America. This study focuses on the northwestern and central parts of the GOM (Fig. 1), where two seismic refraction lines-GUMBO1 (Van Avendonk et al., 2015) and GUMBO2 (Eddy et al., 2018) - revealed the complexity and heterogeneity of the crust (Fig. 2).

The first of two models presented here follows profile GUMBO1 in the northwestern $\mathrm{GOM}$; it crosses the region where two opposing models for the nature of the crust were proposed. The analysis of Mickus et al. (2009) was based on a potential field model constrained by a few old refraction data (Ewing et al., 1960; Hales et al., 1970) and concluded the necessity of extensive volcanism associated with the rifting stage based on the highly variable observed magnetic field. In contrast, the model of Van Avendonk et al. (2015) was based on the new refraction profile denoted as GUMBO1 (Fig. 2a). The study concluded that the rifting resulted in mantle exhumation (Fig. 2b); the presence of significant magnetic anomalies was explained by preexisting crustal fabric. This study addresses the obvious contradiction between these two end-member models via integrative geophysical analysis. Both hypotheses were modeled to test how they correspond or oppose the available geologic and geophysical data.

The second model presented here is aligned with the line GUMBO 2 in the central GOM; it crosses the region where the published ocean-continent boundaries (OCBs) differ the most-up to $140 \mathrm{~km}(87 \mathrm{mi})$ as shown in Figure 1. The integrative approach allowed testing two different OCB locations to see which one correlates better with the multitude of geophysical data sets used for the study.

The following data sets from the public domain were used for the analysis: (1) seismic data (Radovich et al., 2011; Van Avendonk et al., 2015; Eddy et al., 2018), (2) the free-air gravity data from Sandwell et al. (2014), (3) the total magnetic intensity grid from the United States Geological Survey (USGS) airborne and marine magnetic data compilation (Bankey et al., 2002), (4) the topography/bathymetry grid from Smith and Sandwell (1997), (5) density-velocity well logs (Hilterman, 1998) to constrain the physical properties of the sedimentary section, (6) observations from the deep ocean drilling expedition (Buffler and Shipboard Scientific Party, 1984) to constrain the physical properties of the upper continental crust, and (7) a published salt thickness map in the study area (Filina et al., 2015). 


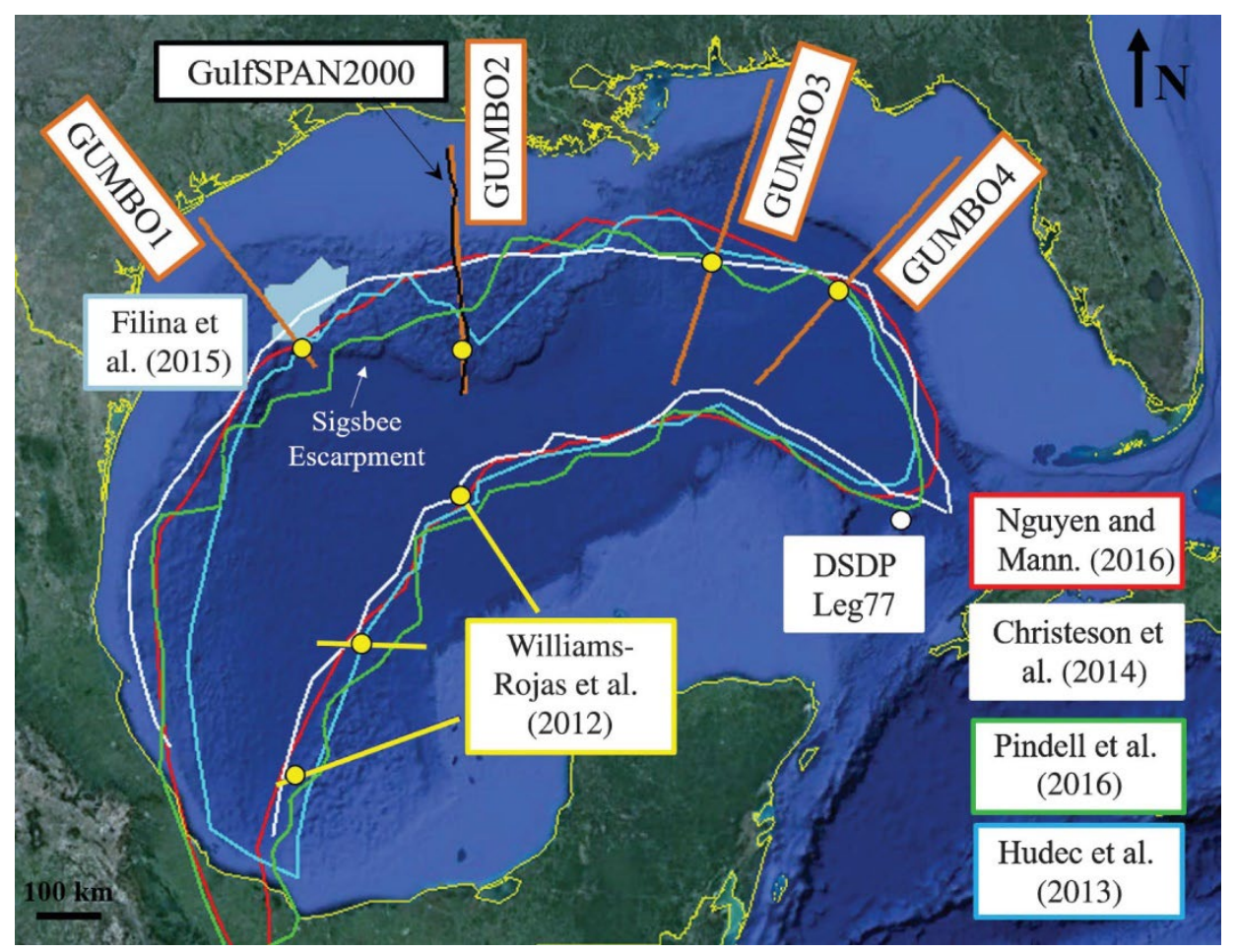

Figure 1. Google Maps screenshot of the GOM. The study area is the northwestern and central parts of the basin. The OCB locations from several recent tectonic models are shown (green, Pindell et al., 2016; light blue, Hudec et al., 2013; white, Christeson et al., 2014; red, Nguyen and Mann, 2016). The white circle shows the DSDP well from Leg 77 (Buffer and Shipboard Scientific Party, 1984) that penetrated the basement and confirmed the presence of intruded continental crust. The orange profiles are four refraction lines from the GUMBO experiment; the lines GUMBO1 (Van Avendonk et al., 2015) and GUMBO2 (Eddy et al., 2018) were used in this study. The gray-shaded polygon is a 3D seismic survey from Filina et al. (2015). The black line shows the seismic reflection profile GulfSPAN2000 from Radovich et al. (2011). The southern edge of the salt is marked by the Sigsbee Escarpment. The yellow circles show the locations of the OCB: from this study for GUMBO1 and GUMBO2, the interpreted OCB from a similar integrated analysis of Liu et al. (2019) for GUMBO3, from Liu (2018) for GUMBO4, and from Filina and Hartford (2019) for three profiles in the Yucatan margin (the yellow lines). 
a) GUMBO1 refraction results

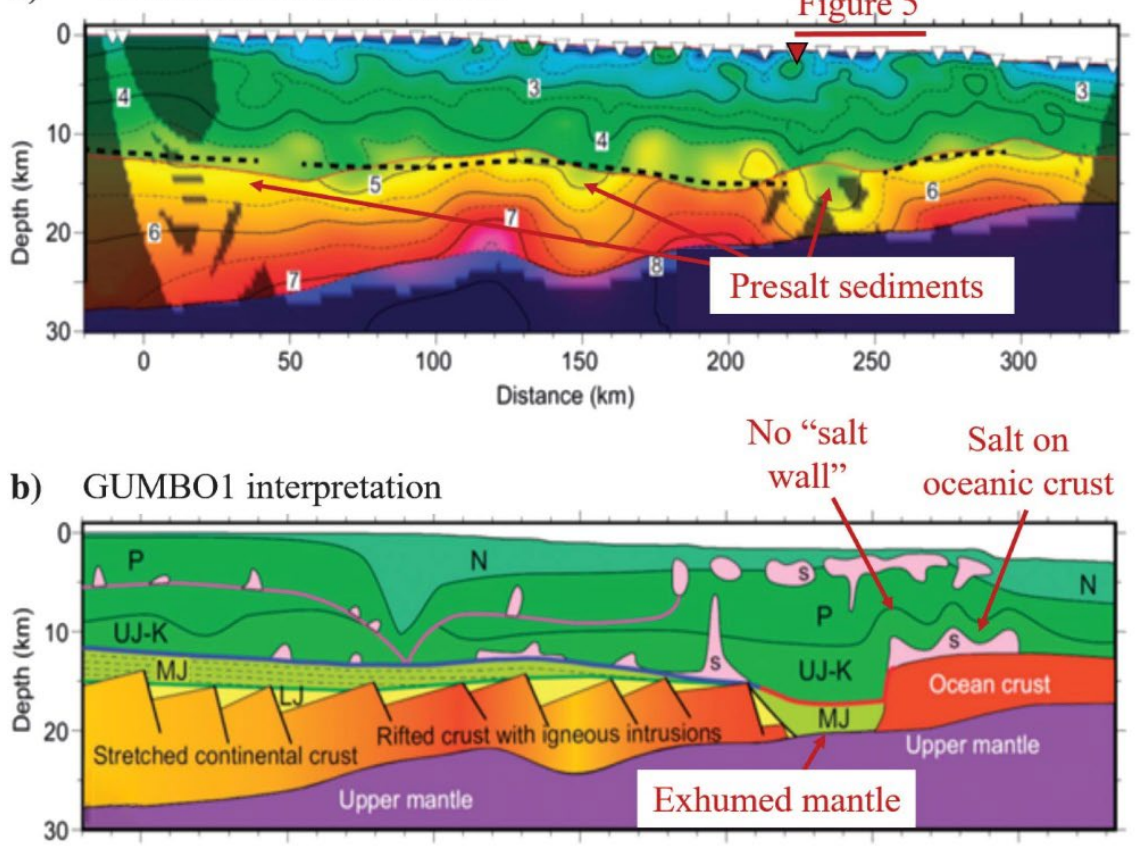

c) $\mathrm{GUMBO} 2$

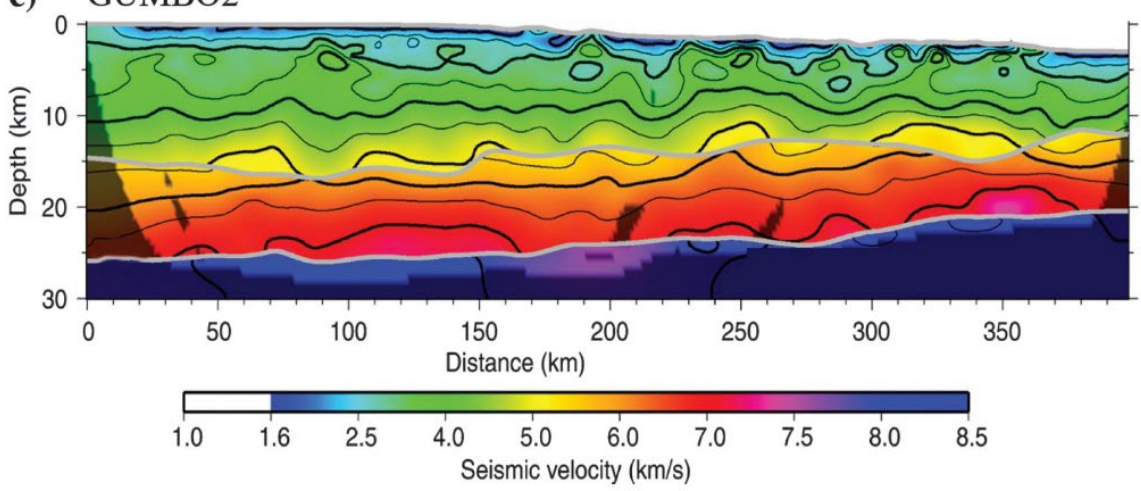

Figure 2. Seismic data used for the study. ( $a$ and $b$ ) The results of the seismic refraction experiment along line GUMBO1 from Van Avendonk et al. (2015) and (c) the results of the seismic refraction experiment for GUMBO2 from Eddy et al. (2018). See the locations of both lines in Figure 1. Sections ( $a$ and c) show compressional seismic velocities VP (in $\mathrm{km} / \mathrm{s})$; the same scale bar applies to both lines shown at the bottom of section (c). Section (b) illustrates the geologic interpretation for GUMBO1 corresponding to the seismic velocities shown in (a). The dashed black line in (a) is the interpreted base of the salt. The zone of slow crustal velocities in the range between 210 and $255 \mathrm{~km}$ of GUMBO1 is interpreted as Jurassic sediments overlying exhumed mantle. Because the interpreted seismic velocity of these Jurassic sediments is in the order of $5-5.5 \mathrm{~km} / \mathrm{s}$, the thick layer of sediments (up to $4 \mathrm{~km}$ ) with the same velocity range was interpreted to overly the hyperextended $(\approx 7 \mathrm{~km})$ continental crust. The red bar in (a) shows the extent of the seismic raytracing test (Fig. 5) performed for the instrument denoted by a red triangle. 


\section{Geologic settings}

Seismic cross sections shown in Figure 2 image multiple subsurface layers: the thick sedimentary cover overlying the crust of various thickness with some pronounced heterogeneities and the top of the mantle. All of these should be included in the integrated subsurface models, and the corresponding physical properties (densities and magnetic susceptibilities) must be properly constrained during the analysis using either well data (sediments, upper crust) or the published values for the rocks of the deeper layers.

The sedimentary section in the GOM exceeds $15 \mathrm{~km}(\sim 49,212 \mathrm{ft})$, and it includes a significant volume of salt that resides at two levels: the deeper salt layer (autochthonous, also called the Louann salt) and the shallower one (allochthonous salt, mobilized Louann salt as clastic sediments filled the basin). It is well known that the presence of salt bodies within the sedimentary section obscures seismic reflection imaging, making it difficult to interpret the base of the salt as well as distorting the subsalt structures. The rock salt has a much higher seismic velocity $(4.5 \mathrm{~km} / \mathrm{s}$; Telford et al., 1990) with respect to most of the sedimentary rocks (1.6-5 km/s as shown in Fig. 2a and 2c). Thus, including proper salt structures in seismic data is crucial for accurate ray tracing (in refraction interpretation) and for migration and depth conversion (in reflection surveying). Moreover, salt also has a significantly lower density than most of the sedimentary section (Telford et al., 1990); thus, it has a negative density contrast with most of the sediments and generally results in a negative gravity anomaly (such as the one seen in Fig. 3a). That is why the joint interpretation of seismic and gravity data can be used to derive a more confident salt model.

The integrated analysis of 3D seismic data and the gravity field in the northwestern GOM (Filina et al., 2015) resulted in a salt-thickness map (Fig. 3b). The salt thickness exceeds $13 \mathrm{~km}(\sim 42,650 \mathrm{ft})$ in the study area - the region known as a "salt wall," which can be clearly seen as a strong negative anomaly in gravity data (Fig. 3a). The southeastern end of the line GUMBO1 crosses this salt wall. However, this thick salt is missing in the seismic refraction model (Fig. $2 \mathrm{a}$ and $2 \mathrm{~b}$ ) causing the errors in the velocity values of the structures beneath the salt. This study aims to test if the lack of the salt wall with the high seismic velocities in the seismic refraction model (Fig. 2a) could result in the slow velocity zone in the crustal layer, leading to the overall conclusion about mantle exhumation (Fig. 2b). 

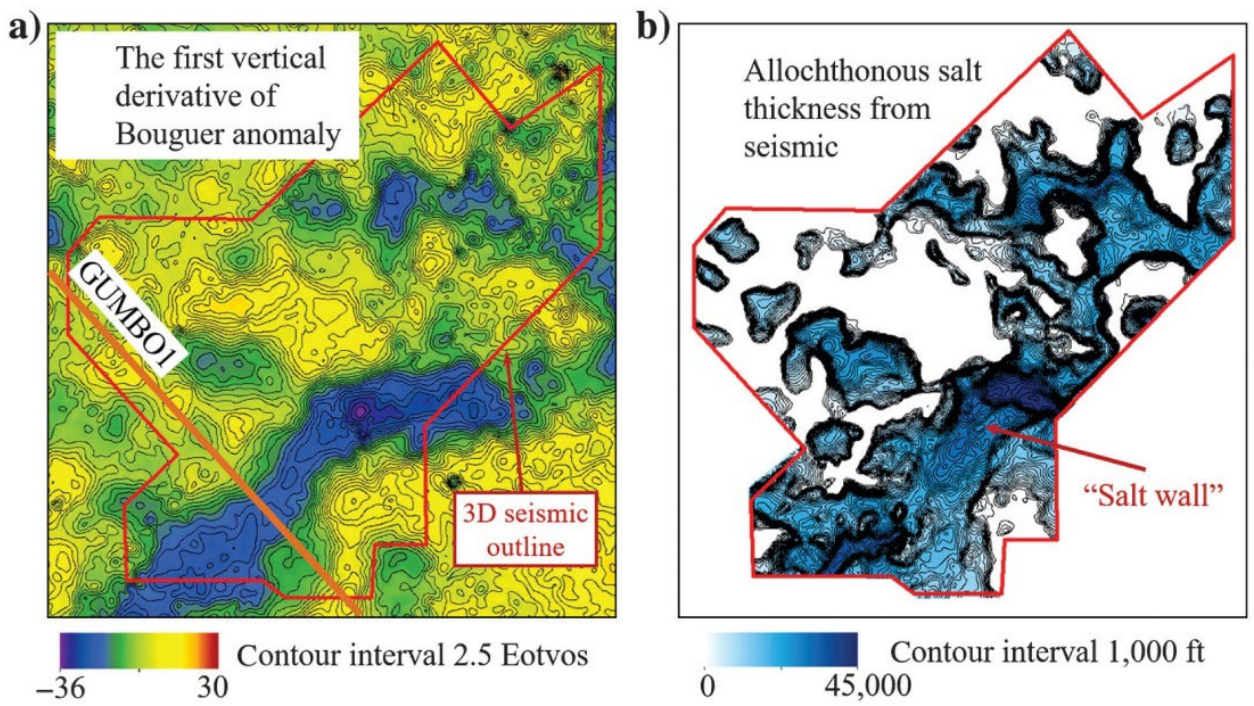

Figure 3. Figure from Filina et al. (2015) illustrating the correlation between (a) the gravity field and (b) the salt thickness from 3D seismic survey. The southeastern end of profile GUMBO1 goes over the salt wall-the region with salt thickness over $13 \mathrm{~km}(\sim 42,650 \mathrm{ft})$ that corresponds to a strong negative gravity anomaly. This salt is missing in the seismic model of GUMBO1 (Figs. 2a and 2b, Van Avendonk et al., 2015) leading to inaccurate velocities for the crustal layers and resulting in exhumed mantle interpretation; see Figs. 4-6).

According to Galloway (2009), the Louann salt was deposited in the northern GOM very early in the history of the basin. This implies that a thin sedimentary section (if any) would be expected between the deeper salt and the top of the crust (basement). However, a few-kilometer-thick sedimentary section below the autochthonous (deep) salt, referred to as "presalt" sediments, is known from seismic reflection data along the Yucatan margin and in the northeastern GOM (Williams-Rojas et al., 2012; Saunders et al., 2016; Horn et al., 2017; O'Reilly et al., 2017). In the study of Filina et al. (2015), shown as a shaded gray polygon in Figure 1, allochthonous and autochthonous salt structures as well as the basement boundary were mapped, concluding no presalt sediments in the study area. In contrast, the study of Van Avendonk et al. (2015) along a seismic refraction line GUMBO1 that crosses the 3D survey coverage from Filina et al. (2015) suggests that an approximately $4-\mathrm{km}$-thick layer of subautochthonous salt sediments is present beneath the salt (Fig. 2b). This conclusion is based on the presence of a zone of slow seismic velocities (5.0-5.5 km/s) in the range between 210 and $255 \mathrm{~km}$ that was interpreted by Van Avendonk et al. (2015) as the presence of "Jurassic sediments" over an exhumed mantle. This interpretation, in turn, implied that for the first $200 \mathrm{~km}$ of the line, the rocks below the Louann salt with velocities up to $5.5 \mathrm{~km} / \mathrm{s}$ should also be attributed to the presalt sedimentary section (Fig. $2 b$ ). Consequently, the thickness of the continental crust varies from approximately $14 \mathrm{~km}$ at the beginning of the line to approximately $6 \mathrm{~km}$ in the center, whereas the crust pinches out at the range of approximately $210 \mathrm{~km}$ (Fig. 2a and 2b). This exhumed mantle concluded 
by Van Avendonk et al. (2015) in the northwestern GOM resembles the overall crustal architecture of hyperextended magma-poor rifted margins of West Iberia-Newfoundland (Pérez-Gussinyé, 2012). The observed strong magnetic variations that cannot be attributed to magmatic addition in this scenario are explained by the presence of preexisting crustal fabric. In addition, the zones of fast seismic velocities in the lower continental crust (i.e., at the distance of $120 \mathrm{~km}$, Fig. 2a) are explained by Van Avendonk et al. (2015) as possible gabbroic intrusions, resulting from adiabatic decompression of the rising asthenospheric mantle during rifting stage. This study aims to test if the thick presalt sediments over hyperextended crust and exhumed mantle, interpreted by Van Avendonk et al. (2015), are supported by observed potential fields.

Both profiles start in the continental domain in the north, and they end over the oceanic crust in the south. The location of the OCB that defines the contact between two domains is still being debated in the study area as is illustrated in Figure 1. In the northwestern GOM, Van Avendonk et al. (2015) put it inbound of the salt wall region (approximately at the distance of $255 \mathrm{~km}$ along the line, Fig. 2b), whereas Filina et al. (2015) suggest the outbound location, closer to the Sigsbee Escarpment. In this study, two different OCB locations - the one proposed by Van Avendonk et al. (2015) and the one near the Sigsbee Escarpment (consistent with Filina et al., 2015) were tested.

In the central GOM, the location of the OCB varies dramatically between published models (Fig. 1). The three models (Christeson et al., 2014; Nguyen and Mann, 2016; Pindell et al., 2016) suggest the OCB location based on the tectonic reconstructions to ensure the tight fit between the Yucatan crustal block and Texas and Louisiana margin. On the other hand, the OCB of Hudec et al. (2013) is based on the interpretation of industry seismic data, suggesting locations up to $140 \mathrm{~km}(87 \mathrm{mi})$ to the south with respect to other models. The seismic lines GUMBO2 and GulfSPAN2000 cross the region under debate. The OCB interpretation of Eddy et al. (2018) supports the Hudec et al.'s (2013) model suggesting that the tectonic reconstructions may need to be revised. In this study, two alternative OCB locations were modeled to see which one agrees better with potential fields.

\section{Integrated geophysical analysis}

The integrated geophysical analysis consists of the following steps: at first, the subsurface model composed of various rock layers (several sedimentary units, upper and lower crusts, and the upper mantle) is built based on seismic data, and the physical properties (densities and magnetic susceptibilities) of each layer are then assigned from the best available sources (discussed below). Once the model is ready, the gravity and magnetic effects due to this model are computed and compared with the measured values (Bankey et al., 2002; Sandwell et al., 2014). As the mismatches between computed and measured potential fields are analyzed, the model is adjusted and the process repeats again until a reasonable fit between the fields is reached. The following criteria are expected for the final model: It should agree with all of the data (seismic, gravity, and magnetics), it should obey all of the known geologic constraints (such as reasonable physical properties), and it should remain geologically valid. 
The physical properties (densities and magnetic susceptibilities) were assigned to the following geologic layers outlined by seismic interpretation:

(1) Water with a density of $1030 \mathrm{~kg} / \mathrm{m} 3$ and zero magnetic susceptibility. This is the best-known boundary in the model (constrained by the data of Smith and Sandwell, 1997), and it was kept unchanged during the analysis.

(2) The nonmagnetic sedimentary section was divided into several layers with density values varying from 2250 to $2550 \mathrm{~kg} / \mathrm{m} 3$. The density assignment was based on the velocity-density pairs published by Hilterman (1998) and used in Filina et al. (2015) to derive the seismic velocity-density relationship for 3D analysis.

(3) Salt was assigned the density of $2150 \mathrm{~kg} / \mathrm{m} 3$ and zero magnetic susceptibility to be consistent with previous models (Filina et al., 2015).

(4) The continental crust was composed of two layers: the upper and the lower crustal units. The final models for the GUMBO1 and GUMBO2 lines have the following density values: $2780 \mathrm{~kg} / \mathrm{m} 3$ (upper) and $2900 \mathrm{~kg} / \mathrm{m} 3$ (lower). These values agree with the findings from DSDP Leg 77 (Buffer and Shipboard Scientific Party, 1984) for the upper crust (averaged density $2780 \mathrm{~kg} / \mathrm{m} 3$ ) and with the published estimates of Christensen (1996) for the lower crust. Magnetic susceptibilities were assigned as $500 \mu \mathrm{cgs}$ for the upper crust and $1000 \mu \mathrm{cgs}$ for the lower one (Hunt et al., 1995).

(5) The oceanic crust was also split in two layers: the top oceanic layer (basalts) and the bottom oceanic layer composed of gabbro. Because the oceanic crust in the GOM has not been drilled, the physical properties were assigned based on the published values and validated throughout the modeling. The density values of 2650 and $2950 \mathrm{~kg} / \mathrm{m} 3$ (Carlson and Herrick, 1990) were given for the top and bottom oceanic layers, respectively, and the corresponding magnetic susceptibilities were 4000 and $8000 \mu \mathrm{cgs}$ (Hunt et al., 1995).

(6) The magmatic intrusions necessary to match the observed magnetic field were assigned the same physical properties as the base layer (gabbro) of the oceanic crust, i.e., density of $2950 \mathrm{~kg} / \mathrm{m} 3$ and a magnetic susceptibility of $8000 \mu \mathrm{cgs}$.

(7) The mantle was given a density of $3300 \mathrm{~kg} / \mathrm{m} 3$ and zero magnetic susceptibility.

The depths to the model boundaries, i.e., the contacts between individual layers, were constrained during the modeling. The data of Smith and Sandwell (1997) were used for the topmost model boundary (bathymetry); the agreement of this boundary with the seismic image further validates proper spatial location of each subsurface model. The top and base of the crust (i.e., basement and Moho boundaries, respectively) were constrained by the seismic refraction data shown in Figure 2 (with the exception of the "exhumed mantle" region of GUMBO1). The sedimentary layers were developed based on the model of Van Avendonk et al. (2015) for GUMBO1 (Fig. 2b), whereas for GUMBO2, they were guided by seismic reflection data along a coincident profile GulfSPAN 2000 from Radovich et al. (2011). 
Two 2D integrated geophysical models were developed along seismic refraction lines (Fig. 2a and 2c) to study the crustal architecture and the tectonic structures of the northwestern and central GOM. Because these targets represent relatively deep regional features, the 2D assumption adopted for modeling remains valid. In contrast, if the focus of the study was on the shallower salt bodies, as shown in Filina et al. (2015), the 3D modeling would be mandatory to properly take into account the effects of the highly variable salt structures.

\section{GUMBO1}

The initial reference model is presented in Figure 4; it was developed based on the interpretation from Van Avendonk et al. (2015) shown in Figure 2b. The overall regional fit was achieved in gravity and magnetic fields with the exception of several key mismatches described below.

The calculated magnetic field shows a distinct magnetic anomaly associated with a transition between the section of nonmagnetic sediments to the highly magnetic oceanic crust at the model range of $255 \mathrm{~km}$ (it is marked as model's OCB in the top panel of Fig. 4). This calculated magnetic anomaly is inboard of a similar signal in the measured field, suggesting the shift in the OCB location to the southeast. This illustrates the lateral sensitivity of the model to the location of the OCB. It requires the OCB to be shifted to the range of $305 \mathrm{~km}$ to obtain a good fit between observed and modeled magnetic fields. The observed magnetic signature also demands the existence of highly magnetic bodies in the lower crust, some of which are coincident with the zones of high seismic velocities (Fig. 2a). At least one of these magnetic intrusive bodies is reversely magnetized (it is colored in a lighter shade of gray in Fig. 4).

In gravity, the overall regional fit between observed and measured fields was achieved for the continental domain (the first $200 \mathrm{~km}$ along GUMBO1, Fig. 4). However, this fit requires anomalously high density values for the continental crust layers $(2850 \mathrm{~kg} / \mathrm{m} 3$ for the upper crust and $3000 \mathrm{~kg} / \mathrm{m} 3$ for the lower one). If the more realistic values of 2780 and 2900 $\mathrm{kg} / \mathrm{m} 3$ were assumed for the continental crust layers, the computed gravity response for the first $200 \mathrm{~km}$ of the model would be approximately $20 \mathrm{mGal}$ lower that the one shown in Figure 4, causing a dramatic regional misfit. Because the gravity signature depends primarily on two factors - the density contrasts between the layers in the model and the geometries/thicknesses of these layers - in theory, they can both be adjusted during modeling. In practice, the depths and thicknesses of the individual rock units are constrained from refraction data, so the density remains the only parameter available for modification to obtain a reasonable regional match between observed and computed gravity data. In the case of the reference model (Fig. 4), the densities of both crustal units have to be anomalously high as reported above. 


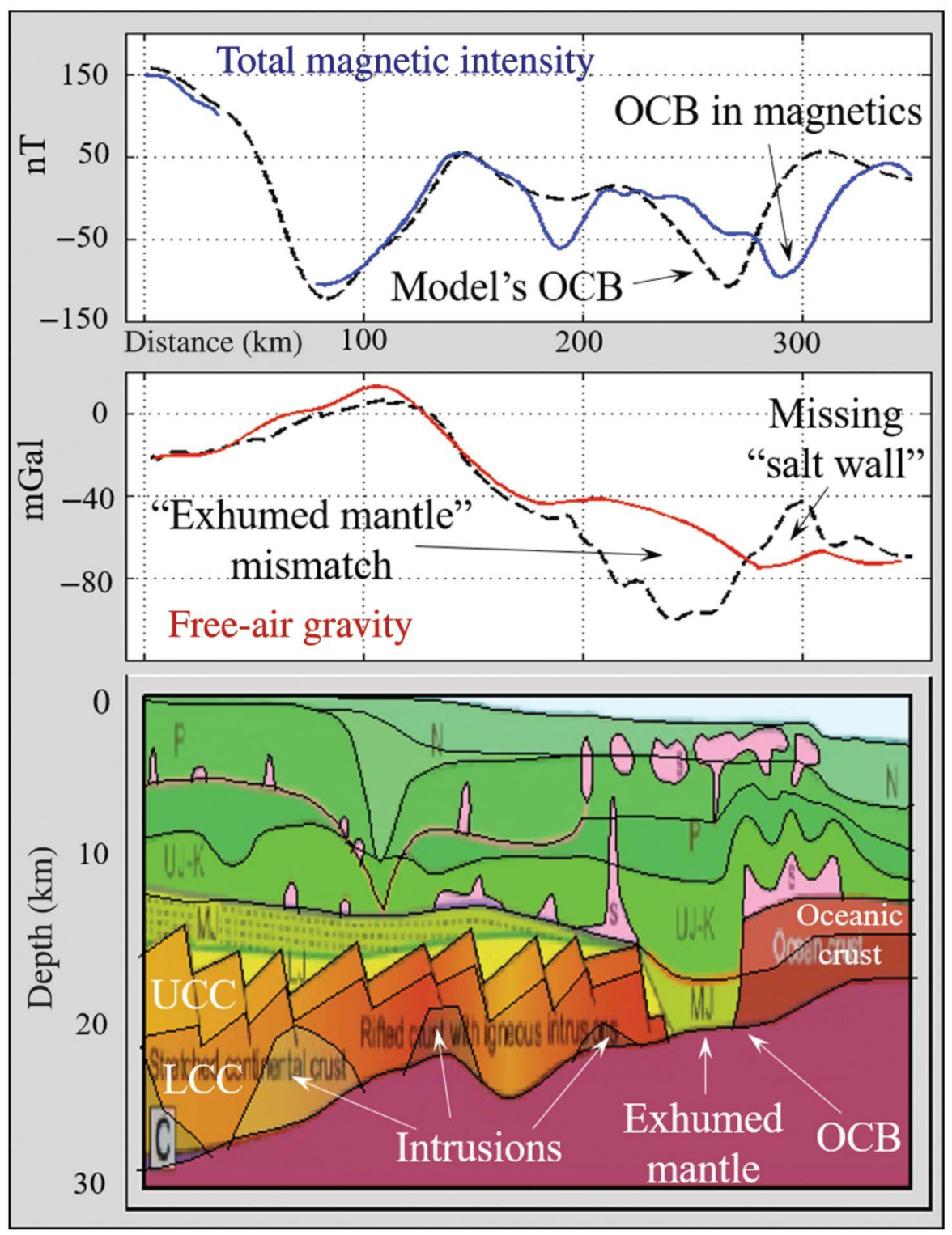

Figure 4. The initial reference potential fields analysis for GUMBO1 based on the interpretation of Van Avendonk et al. (2015) (the image beneath the model panel at the bottom). The top two panels show the fit in magnetic and gravity fields, the observed data are solid lines, and the calculated responses due to the model in the bottom panel are dashed black lines. UCC and LCC indicate the upper and lower continental crustal layers. The intrusive bodies in the lower crust are required to explain the observed magnetic signature. The intrusive body with reversed magnetic polarity is colored in a lighter shade of gray. Please refer to the text about the physical properties of each layer in the model. The mismatches between the observed and calculated potential fields indicate that this model requires some adjustments (see the text for details). Vertical exaggeration of the cross section is nine. 
Because the basement was not ever drilled in the study area, no hard constraints can be posted on the physical properties of the upper crust. However, there is the DSDP well in the southeastern part of the basin (DSDP Leg 77, site 538A; Buffer and Shipboard Scientific Party [1984], shown as a white circle in Fig. 1) that penetrated early Paleozoic metamorphic rocks intruded with Early Jurassic diabase dikes with normal and reverse magnetic polarities. The average density value of the upper crustal rocks from that well is $2780 \mathrm{~kg} / \mathrm{m} 3$. With the lack of better constraints in the study area, the measurements from that well were used to validate the density of the upper crust derived during the modeling as well as to explain the presence of the reversely magnetized intrusive body revealed by magnetic modeling.

In addition to the high crustal densities required to fit gravity in the continental domain of the initial model (Fig. 4), two large mismatches of opposite sign were observed. The smaller negative one reflects the missing salt in the sedimentary section. The larger positive misfit coincides with the region of exhumed mantle, and it indicates that higher densities (i.e., crustal units instead of Jurassic sedimentary layer) are required in the subsurface to better correspond with the measured gravity.

As mentioned above, a reasonable regional fit in gravity data requires anomalously high density values for the hyperextended crust (up to $7 \mathrm{~km}$ thin). This crust is overlain by a thick presalt sedimentary section that was interpreted by Van Avendonk et al. (2015) based on seismic velocities of $0.5-5.5 \mathrm{~km} / \mathrm{s}$ (Fig. 2a and $2 \mathrm{~b}$ ) derived from the raytracing, i.e., propagation of seismic energy through the model. As an alternative interpretation, the subautochthonous sedimentary section with seismic velocities from 5.0 to $5.5 \mathrm{~km} / \mathrm{s}$ may be attributed to the upper crust. This will increase the thickness of the stretched continental crust to approximately $17 \mathrm{~km}$ at the northwestern end of the line and to approximately 10 $\mathrm{km}$ in the center and near the OCB as well as decrease the densities to more realistic values (2780 and $2900 \mathrm{~kg} / \mathrm{m} 3$, respectively).

I hypothesize that the zone of the slow seismic velocities at the crustal level (Fig. 2a, the distances between 210 and $255 \mathrm{~km}$ ) resulted from the raytracing through the sedimentary section that lacked the large salt volume (i.e., missed "salt wall"). To test this hypothesis, seismic raytracing was performed using software from Burger et al. (2006) for two models shown in Figure 5. The data for one instrument deployed at the model distance of $240 \mathrm{~km}$ (shown as the red triangle in Fig. 2a) were digitized from Figure 2 of Van Avendonk et al. (2015) for the range of sources shown by a red bar in Figure 2a. The first model did not have thick salt in the sedimentary section, but it had slower deep layers, i.e., similar to "sediments over exhumed mantle" from Van Avendonk et al. (2015), and the second model included the large salt body in the sediments overlying the 10-km-thick stretched continental crust (as suggested by an alternative interpretation - no presalt sediments and thus thicker crust). Figure 5 shows that the computed seismic traveltimes for both models match the observed data, supporting the statement that the missing salt wall in the sedimentary section may result in an artificial exhumed mantle underneath. Although this test uses somewhat oversimplified models (i.e., layers with constant velocities), it illustrates the nonuniqueness of the interpretation of seismic refraction data alone. 

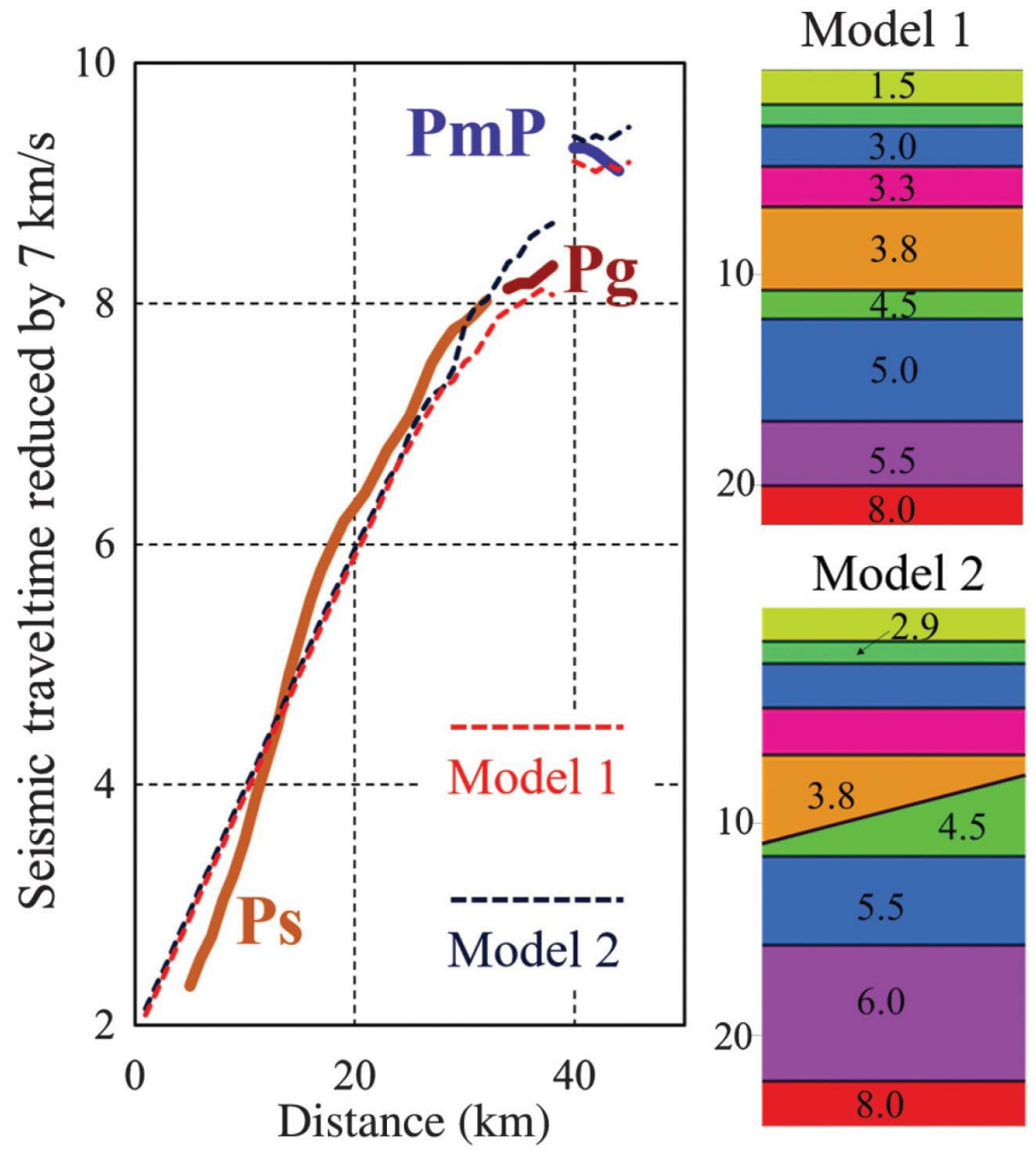

Figure 5. The seismic traveltimes through the disputed region along line GMBO1. The location of the instrument (the red triangle) and extent of the models are shown in Figure 2a. The thick curves are observed data digitized from Figure 2 of Van Avendonk et al. (2015); Ps and Pg are the refractions within sediments and from the basement, respectively, and PmP is the reflection from the Moho boundary. The dashed curves are computed traveltimes (with the software from Burger et al., 2006) for two models shown on the right; the numbers are the VP velocities in $\mathrm{km} / \mathrm{s}$. The top model (model 1 ) does not include the salt wall, but it has the exhumed mantle, and the bottom model (model 2) includes the salt wall over the $10 \mathrm{~km}$ thick stretched continental crust (as suggested by an alternative interpretation without presalt sediments). The top portions of both models are identical.

The final model (Fig. 6) has the following changes with respect to the initial reference model: the missing "salt wall" is added per constraints from 3D seismic (Filina et al., 2015; Fig. 3), exhumed mantle is removed as suggested by gravity mismatch (Fig. 4), and consistent with the seismic refraction test (Fig. 5) the OCB is shifted to the southeast closer to the Sigsbee Escarpment to acknowledge magnetic signal in Figure 4, and the continental 
crust is thickened by removing the layer of presalt sediments yielding more realistic crustal density values (2780 and $2900 \mathrm{~kg} / \mathrm{m} 3$ for the upper and the lower crustal layers, respectively). As the final model (Fig. 6) agrees with all the data sets used in the study, it represents the preferred solution for the cross section GUMBO1. It is worth mentioning that this final model includes some sediments beneath the Louann salt at the range of $300 \mathrm{~km}$ near the OCB (Fig. 6). These do not represent presalt sediments; instead, these are younger than the salt deposits that were overridden by a deep salt (Hudec et al., 2013).

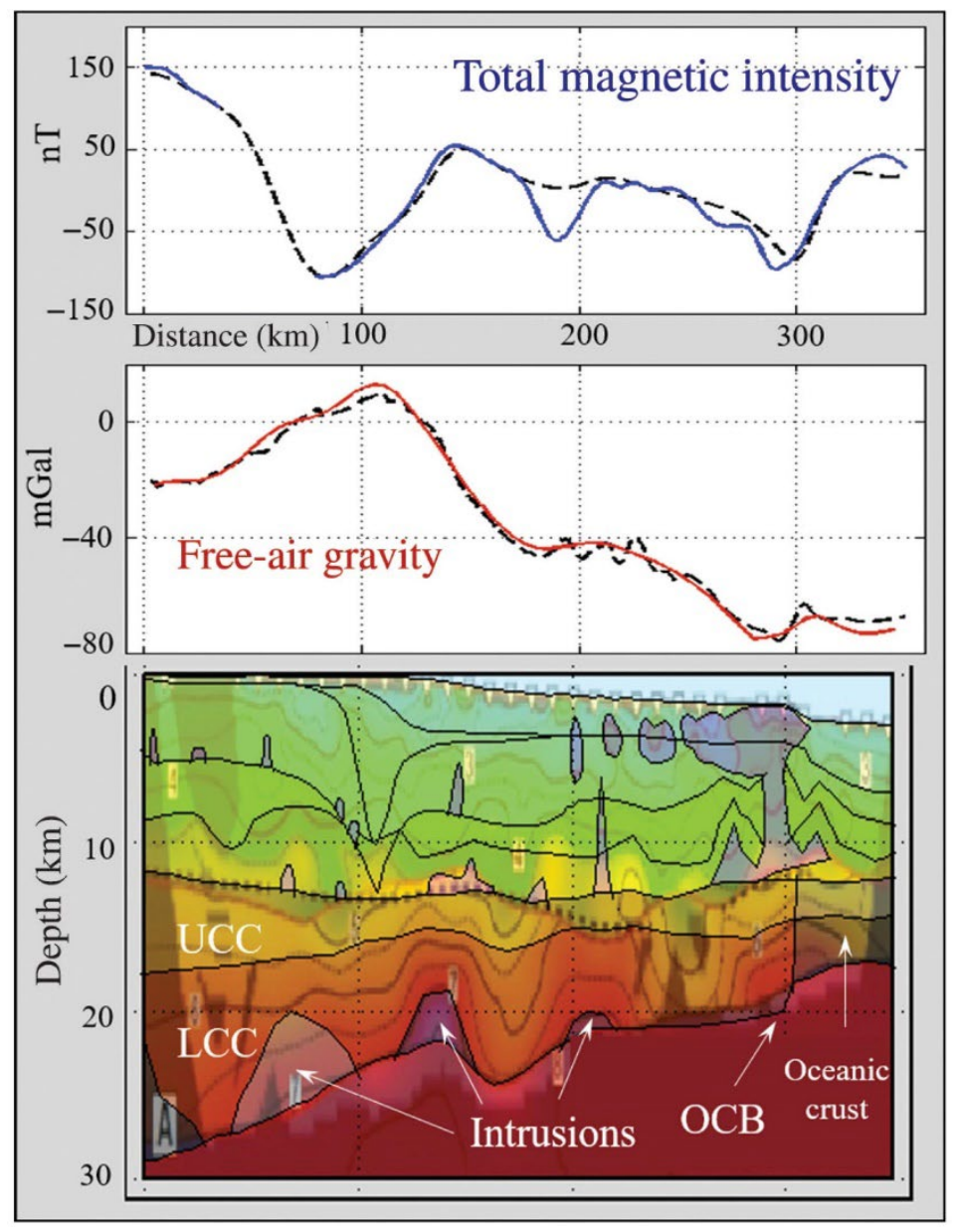

Figure 6. The final potential fields model for the GUMBO1 line. This model incorporates the missing salt wall and ignores exhumed mantle and "presalt sediments" interpreted by Van Avendonk et al. (2015). The error in the initial model (Fig. 4) is attributed to missing thick salt in salt wall region. This model is consistent with GUMBO2 in terms of total crustal thickness (approximately $10 \mathrm{~km}$ thick continental crust near OCB, approximately $6.5 \mathrm{~km}$ thick oceanic crust) and the overall OCB location (near the Sigsbee Escarpment). The same intrusive bodies in the lower crust are included into this model, as in the one shown in Figure 4. The physical properties of each layer are described in the text. Vertical exaggeration is nine (the same as shown in Fig. 4). 


\section{GUMBO2}

A 2D model aligned with refraction line GUMBO2 was developed with the objective to test different OCB locations proposed in the central GOM (Figure 1). The preferred potential fields model is shown in Figure 7. In this model, the OCB was placed at the range $340 \mathrm{~km}$ near the Sigsbee Escarpment, where the crustal thickness changes from approximately 10 $\mathrm{km}$ in the continental domain to approximately $7 \mathrm{~km}$ (the thickness of normal oceanic crust). Eddy et al. (2018) define the OCB for GUMBO2 line in the range of $310 \mathrm{~km}$.

The magnetic signal along GUMBO2 includes several significant anomalies (Fig. 7) that are coincident with the regions of high seismic velocities in refraction data (Fig. 2c). Similar to GUMBO1, these were interpreted as magmatic intrusive bodies that were emplaced in the lower continental crust presumably during the rifting stage, which is consistent with the interpretation of Eddy et al. (2018). The similar high-velocity regions were also outlined at the base of the lower continental crust of the profile GUMBO3 (Eddy et al., 2014) and were modeled by Liu et al. (2019) as highly magnetic and dense intrusive bodies. To match the observed magnetic anomalies, the magnetic susceptibility of these intrusive bodies should be $8000 \mu \mathrm{cgs}$, which is the same as the magnetic property of the lower oceanic crust in the model and is within the possible range for mafic igneous rocks according to Hunt et al. (1995).

Figure 7 on next page

Figure 7. The preferred potential fields model for line GUMBO2 through the central GOM. See Figure 4 for description. The sedimentary layers in the model constrained by the reflection seismic (Radovich et al., 2011), whereas the crustal structures are from GUMBO2 (Eddy et al., 2018, Fig. 2c). The physical properties (densities and magnetic susceptibilities) assigned to the layers are the same as for the preferred model for GUMBO1 (Fig. 6) and are described in the text. OC denotes oceanic crust. The OCB for this model is at the range of $340 \mathrm{~km}$; interpreted OCB from Eddy et al. (2018) is at approximately $310 \mathrm{~km}$. Two alternative ОСВ locations from published models are shown; one of them at the range of $190 \mathrm{~km}$ (as in Christeson et al., 2014; Nguyen and Mann, 2016) was also tested (see the text for details). The vertical exaggeration is 8.5 . 


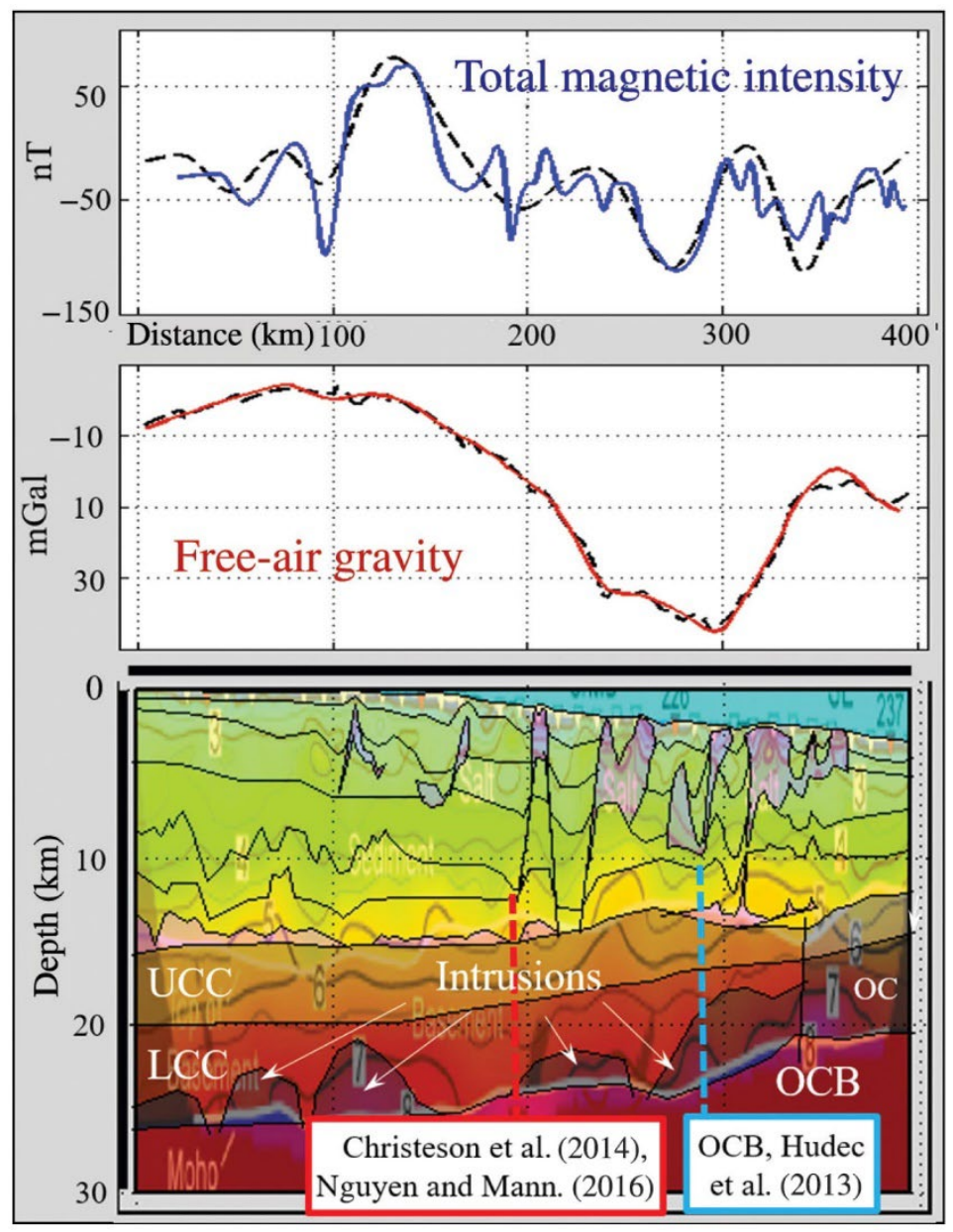

Caption for Figure 7 on previous page

\section{Discussion}

It is well known that the solution of the inverse problem of potential fields is not unique. In my models, the depths to the layers are constrained by seismic data, and they are fixed during the modeling process. Thus, the physical properties and the locations of the subsurface structures (i.e., OCB or intrusive bodies) are the only two "knobs" that can be used to obtain a desirable fit between the observed and calculated potential fields. The densities of sedimentary section are constrained based on the multiple well data from Hilterman (1998). The density of the upper crust was validated from the only sample of the extended continental crust in the GOM (basement penetration in DSDP Leg77, although it is far away of the study area), and it is also within the expected range according to Christensen and Mooney (1995). The physical properties for the rest of the model were derived through the modeling, and they are also within the published ranges (Carlson and Herrick, 1990; Christensen and Mooney, 1995; Hunt et al., 1995). 
Overall, the integrative analysis of multiple geophysical data sets presented here, namely, seismic reflections and refraction data and potential fields, allows testing various geologic scenarios. For the line GUMBO1, it shows that the hypothesis about mantle exhumation in the northwestern GOM is not supported by gravity and magnetics (Fig. 4). In contrast, the modeling is more consistent with the magma-assisted rifting hypothesis, resulted in thinned and intruded continental crust without significant presalt sediments (Fig. 6). The inferred zones of dense and highly magnetic rocks with fast VP values may be interpreted as either "rifted volcanic margin" (consistent with Mickus et al., 2009) or as possible gabbroic intrusions, resulting from adiabatic decompression of the rising asthenospheric mantle during the rifting stage (as suggested by Van Avendonk et al., 2015). Potential field data are inadequate to discriminate between these two possibilities. However, the former is in agreement with the results from the DSDP basement well mentioned above, which encountered the upper continental crust intruded by Early Jurassic diabase dikes with various magnetic polarities (Buffer and Shipboard Scientific Party, 1984). That is why the stretched and thinned continental crust with multiple magmatic additions presumably emplaced during magma-assisted rifting is concluded in the northwestern GOM based on the preferred model for the line GUMBO1 (Fig. 6). The present study does not intend to refute the results of Van Avendonk et al. (2015) from the analysis of refraction data only. Instead, this study offers an alternative interpretation and aims to illustrate the benefits of integrative approach to analysis of geophysical data.

For profile GUMBO2, the preferred potential field model (Fig. 7) has the OCB located at the range $340 \mathrm{~km}$ near the Sigsbee Escarpment. This deviates dramatically from several tectonic models shown in Figure 1. The alternative OCB location is suggested by the models of Christeson et al. (2014) and Nguyen and Mann (2016) at the range of $190 \mathrm{~km}$. Because the depths to the layers in the model are constrained by refraction data, this alternative OCB location makes the assumed oceanic crust in the middle of the line to be $10-11 \mathrm{~km}$ thick, which is thicker than normal oceanic crust. Despite that this crustal thickness makes the hypothesis of continental affiliation in the disputed region to be preferable, this alternative OCB location was also modeled. For the alternative model (i.e., OCB location at the range of $190 \mathrm{~km}$ ), the gravity fit remains reasonable because the decrease in density between the upper continental crust $(2780 \mathrm{~kg} / \mathrm{m} 3)$ to oceanic layer 2 (basalts, $2650 \mathrm{~kg} / \mathrm{m} 3$ ) is somewhat compensated by the density increase from the lower continental crust (2900 $\mathrm{kg} / \mathrm{m} 3$ ) to oceanic layer 3 (gabbro, $2950 \mathrm{~kg} / \mathrm{m} 3$ ). In magnetics, to maintain the fit between the observed and calculated anomalies, the magnetic susceptibility of the oceanic crust must decrease from $8000 \mu \mathrm{cgs}$ for the preferred model (Fig. 7) to zero for the alternative one.

The seismic velocities of the crust in the disputed region along GUMBO2-in the range of 190 to $340 \mathrm{~km}$ - vary from 5 to $6.5 \mathrm{~km} / \mathrm{s}$ for the upper layer and 6.5 to $7 \mathrm{~km} / \mathrm{s}$ for the lower one (Fig. 2c). These seismic velocities may be assigned to oceanic and continental crustal units, and it is not possible to discriminate between these domains just on the seismic velocities alone. Eddy et al. (2018) compare the velocity versus depth profile of the crustal layer of GUMBO2 with the other rifted continental margins and conclude that the nature of the crust in the center of the GUMBO2 line is continental and is consistent with an intermediate volcanic rifted margin. Despite that the continental affiliation also appears to be more likely from the integrated analysis (Fig. 7); the potential fields, however, do not offer 
a unique distinction. As described earlier, the alternative model with the OCB at the range of $190 \mathrm{~km}$ would suggest thicker than normal and nonmagnetic oceanic crust. The thicker oceanic crust has been recorded in the northeastern GOM for the GUMBO3 (Eddy et al., 2014), although the seismic velocities for the oceanic domain of that line are much higher (6-7 km/s for the upper crust, and exceeding $7 \mathrm{~km} / \mathrm{s}$ for the lower one). In addition, a similar integrated analysis along GUMBO3 (Liu et al., 2019) suggests that the oceanic crust requires high magnetic susceptibility values to explain observed magnetic signals, which contradicts the nonmagnetic oceanic crust required for an alternative GUMBO2 model. Another argument toward the continental nature of the crust in the central GOM is the presence of the well-known prolific petroleum system over that region (Whaley, 2006; Dribus et al., 2008) indicating warm enough conditions for the sedimentary section within the basin to mature the source rock and generate hydrocarbons. The felsic upper continental crust has higher radioactive heat production than either of mafic lower continental crust or even more mafic oceanic crust (Furlong and Chapman, 2013). Therefore, the appreciable thickness of the upper crustal unit is usually inferred to explain the presence of the extended hydrocarbon system. If the hyperextended regime was assumed with the upper crust being rifted away, resulting in exhumation of the lower continental crust, the radiogenic heat production would be dramatically less than for the felsic upper crust, making the presence of a prolific petroleum system less likely. Therefore, the existence of an extended hydrocarbon system in the central GOM would also lean toward the continental hypothesis. However, the working petroleum system can be developed over the oceanic crust (Rajmon and Egorov, 2015), although to date only a few examples of such settings are known. Thus, the presence of a petroleum system also does not allow a unique distinction between the two crustal domains. Another way to discriminate between continental and oceanic domains is to examine the VPNS ratio for the crustal units (Christensen and Mooney, 1995). This analysis was performed for GUMBO lines 3 and 4 (Duncan, 2013). Unfortunately, no VS values are reported for GUMBO2 line by Eddy et al. (2018), so the lithology of the disputed region in the central GOM cannot be determined based on the VPNS ratio.

The preferred model for line GUMBO2 suggests the OCB at the range of $340 \mathrm{~km}$ that contradicts several tectonic models shown in Figure 1. These models assume that the northwestern and central GOM are conjugate margins for the western Yucatan. An example of such prebreakup reconstruction from Eddy et al. (2014) is shown in Figure 8 (note that the tectonic model of Eddy et al. [2014] is the same as the one described by Christeson et al. [2014], so the corresponding OCB is shown in Fig. 1 in white). The OCB for all of the models in Figure 1 with the exception of the model of Hudec et al. (2013) is forced to be much landward than the one concluded here to ensure a tight fit with the Texas-Louisiana margin similar to the one shown in Figure 8. 


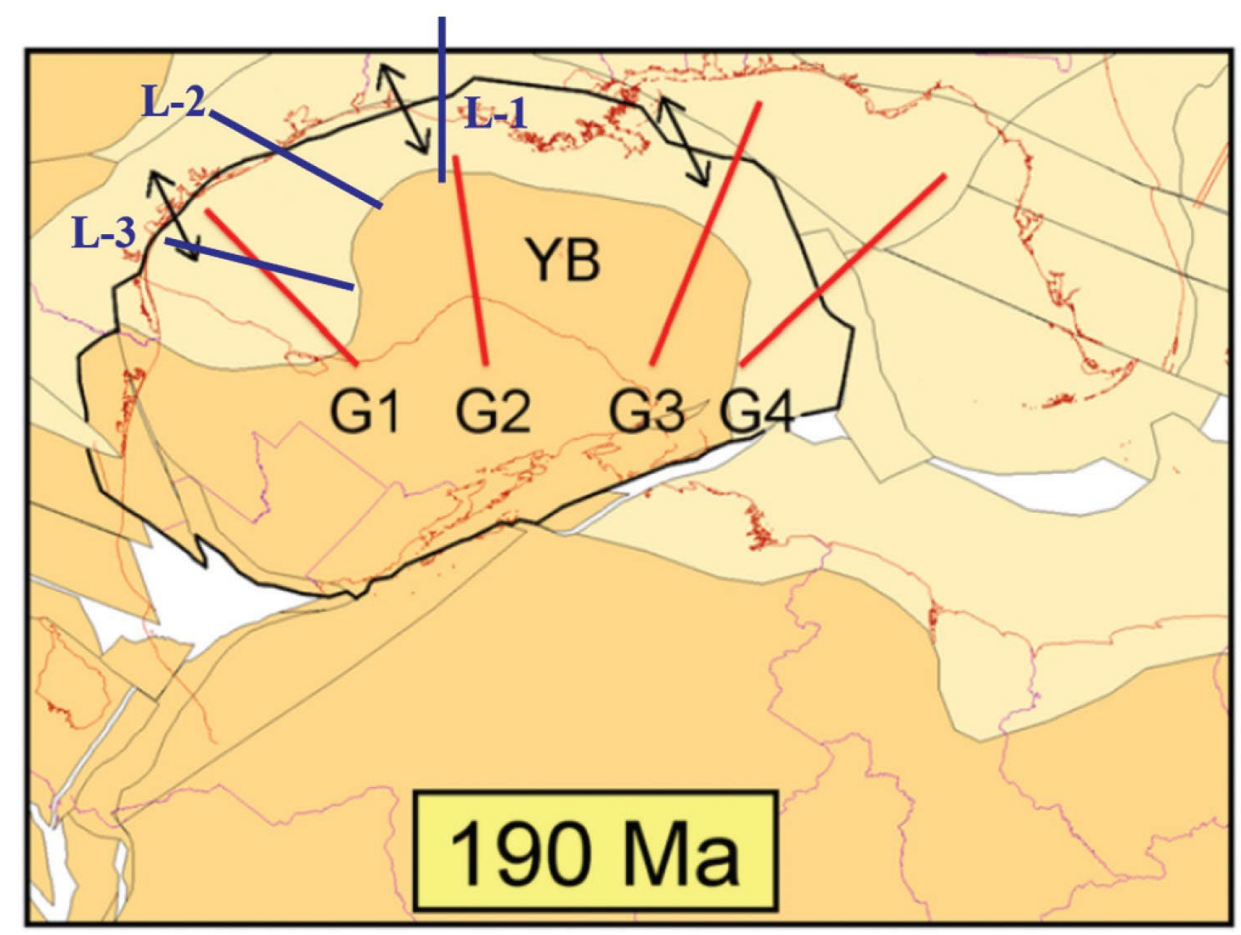

Figure 8. Tectonic reconstruction from Eddy et al. (2014). Superimposed are the profiles' four GUMBO lines (red, denoted G1-G4) and the lines from Williams-Rojas et al. (2012) (shown in blue). All lines from Williams-Rojas et al. (2012) clearly show the presence of a thick presalt section, whereas no presalt section is reported for profile GUMBO2, denoted as G2 (Eddy et al., 2018), which agrees with the results of this study. The presence of the presalt sediments is disputed for the line GUMBO1 (denoted as G1) by this study (Figs. 4-6).

The OCB from Hudec et al. (2013) is closest to the one shown in the preferred model (Fig. 7). The tectonic reconstruction of Hudec et al. (2013) also positions the western margin of the Yucatan crustal block against the Texas-Louisiana coast. However, the formation of the thinned and stretched continental crust all the way to the Sigsbee Escarpment in the central GOM is explained by the stretching during the final stages of the basin opening, after the deposition of the Louann salt. According to Hudec et al. (2013), the oceanic crust in the GOM is formed simultaneously in the western and eastern parts of the basin, whereas the central GOM (crossed by the line GUMBO 2) was the last one to break up; thus, it was the subject for the most extension. Consequently, the tectonic model of Hudec et al. (2013) developed based on the analysis of the industry seismic data throughout the GOM is the closest one to the OCB near the Sigsbee Escarpment concluded by this study.

The analysis presented here suggests no presalt sediments in the study area (Figs. 6 and 7). This lack of presalt deposits in the northwestern GOM (i.e., for the line GUMBO1) is consistent with the results of the 3D seismic reflection survey in that region (Filina et al., 2015). No presalt deposits in the central GOM were also concluded by Eddy et al. (2018) for GUMBO2 based on the seismic velocities from seismic refractions (Fig. 2c) and by 
Radovich et al. (2011) for seismic reflection line GulfSPAN2000. However, the lack of presalt sediments in the northwestern and central GOM contradicts to the thick presalt deposits on the conjugate margin (Fig. 8). Williams-Rojas et al. (2012) report several kilometers thick presalt sedimentary section imaged along three lines (shown in the blue in Fig. 8). Moreover, several recent seismic surveys reported by Saunders et al. (2016), O'Reilly et al. (2017), and Horn et al. (2017) confirm the presence of the presalt deposits along the western Yucatan margin. This apparent mismatch in distribution of the presalt sediments among conjugate margins needs to be investigated further.

The integrated approach in geophysical data analysis presented in this study implies joint interpretation of several independent geophysical data sets that are acquired during different surveys and at different times. The major objective of integrated analysis is to develop the best subsurface model that agrees not only with all of the data but also with all available geologic constraints (such as physical properties either from wells or from assumed rock types), as well as remains geologically reasonable. Because all of the data sets represent the geophysical signals over the same subsurface rocks, their combined analysis yields a more reliable and robust solution than the one resulted from a single method.

\section{Conclusion}

Integrated geophysical modeling was performed for two profiles in the northwestern and central parts of the GOM to reveal the nature of the crust and to constrain the overall architecture of the passive continental margin. Based on these models, which combined seismic, gravity, magnetic, and well data, the following conclusions were drawn:

(1) The crust in the northwestern and central GOM is stretched and thinned continental; it has a total thickness up to $10 \mathrm{~km}$ and is intruded with abundant magmatic material. A series of dense and highly magnetic intrusive bodies is coincident with fast seismic velocity regions in the lower continental crust interpreted in both modeled lines. One of these modeled magmatic intrusions requires a reversed magnetic polarity. The emplacement of the magmatic material is presumably related to the rifting stage of the basin formation, although the timing cannot be established confidently with any of the remote sensing geophysical methods. Nevertheless, this conclusion is consistent with the basement samples from DSDP Leg 77 that encountered the presence of rift-related Early Jurassic diabase dikes with normal and reversed magnetic signatures.

(2) The boundary between oceanic and continental domains is located near the Sigsbee Escarpment for GUMBO1 and GUMBO2. This is consistent with the results from published 3D seismic reflection survey in the northwestern GOM and with seismic refraction experiment in the central part of the basin.

(3) The analysis presented here does not support the presence of thick presalt sediments, neither for GUMBO1 nor for GUMBO2. This conclusion is also consistent with previously published 2D and 3D seismic reflection surveys as well as with seismic refractions for GUMBO2. The presalt sediments appear to be forced in the initial interpretation of refraction data along GUMBO1 based on the presence of a 
low-velocity section immediately above the mantle that is artificial because of the incorrect salt model (i.e., the missing "salt wall").

(4) The lack of presalt deposits in the study area appears to mismatch the thick section of presalt sediments along the western Yucatan margin that is believed to be the conjugate to the study area by many published tectonic models. This mismatch needs to be investigated further.

This study also illustrates the overall importance of the integrative approach in geophysical data analysis that allows validation of the results derived from a single geophysical method (such as refraction or reflection seismic) with other available geologic and geophysical data sets (such as publicly available gravity and magnetic fields and well logs) to ensure agreement with all of the data.

Acknowledgments - The author is grateful to the editor-in-chief B. Nemeth, the assistant editor D. Herron, associate editor B. Horn, N. Bundalo, and two anonymous reviewers for thorough and comprehensive reviews. Many thanks go to K. Chan for providing an academic license to the GM360 software that was used for potential field modeling.

Data and materials availability - Data associated with this research are available and can be obtained by contacting the corresponding author.

About the author - Irina Filina received a PhD (2007) in geophysics from the University of Texas at Austin. After working in the exploration and production technology team of Hess Corporation for eight years, she joined the University of Nebraska-Lincoln. Her research is focused on tectonic history of the Gulf of Mexico as well as on crustal structures and recent seismicity in Nebraska.

\section{References}

Bankey, V., A. Cuevas, D. Daniels, C. Finn, I. Hernandez, P. Hill, R. Kucks, W. Miles, M. Pilkington, C. Roberts, W. Roest, V. Rystrom, S. Shearer, S. Snyder, R. Sweeney, J. Velez, J. D. Phillips, and D. Ravat, 2002, Digital data grids for the magnetic anomaly map of North America: US Geological Survey Open-File Report 02-414.

Bird, D., K. Burke, S. Hall, and J. Casey, 2005, Gulf of Mexico tectonic history: Hotspot tracks, crustal boundaries, and early salt distribution: AAPG Bulletin, 89, 311-328, doi: 10.1306/10280404026.

Buffler, R. X., Shipboard Scientific Party, 1984, Initial report of the Deep Sea drilling project: US Government Printing Office 77, 279-336.

Burger, H. R., A. F. Sheehan, and C. H. Jones, 2006, Introduction to applied geophysics: Exploring the shallow subsurface: W. W. Norton and Company.

Carlson, R. L., and C. N. Herrick, 1990, Densities and porosities in the oceanic crust and their variations with depth and age: Journal of Geophysical Researches, 95, 9153-9170, doi: 10.1029/JB095i B06p09153.

Christensen, N., and W. Mooney, 1995, Seismic velocity structure and composition of the continental crust: A global view: Journal of Geophysical Research Atmospheres, 100, 9761-9788, doi: 10.1029/ 95JB00259. 
FILINA, INTERPRETATION 7 (2019)

Christensen, N. I., 1996, Poisson's ratio and crustal seismology: Journal of Geophysical Research: Solid Earth, 101, 3139-3156, doi: 10.1029/95JB03446.

Christeson, G. L., H. J. A. Van Avendonk, I. O. Norton, J. W. Snedden, D. R. Eddy, G. G. Karner, and C. A. Johnson, 2014, Deep crustal structure in the eastern Gulf of Mexico: Journal of Geophysical Research: Solid Earth, 119, 6782-6801.

Dribus, J. R., M. Jackson, and K. Kapoor, 2008, The prize beneath the salt: Oilfield Review, 20, 4-17.

Duncan, M. H., 2013, The Northeastern Gulf of Mexico: Volcanic or passive margin? Seismic implications of the Gulf of Mexico Basin opening project: M.Sc. thesis, University of Texas.

Eddy, D., H. Van Avendonk, G. Christeson, and I. Norton, 2018, Structure and origin of the rifted margin of the northern Gulf of Mexico: Geosphere, 14, 1804-1817.

Eddy, D., H. Van Avendonk, G. Christeson, I. Norton, G. Karner, C. Johnson, and J. Snedden, 2014, Deep crustal structure of the northeastern Gulf of Mexico: Implications for rift evolution and seafloor spreading: Journal of Geophysical Research: Solid Earth, 119, 6802-6822, doi: 10.1002/ 2014JB011311.

Ewing, J., J. Antoine, and M. Ewing, 1960, Geophysical measurements in the western Caribbean Sea and in the Gulf of Mexico: Journal of Geophysical Research, 65, 4087-4126, doi: 10.1029/JZ065 i012p04087.

Filina, I., N. Delebo, G. Mohapatra, C. Coble, G. Harris, J. Layman, M. Strickler, and J. P. Blangy, 2015, Integration of seismic and gravity data-A case study from the western Gulf of Mexico: Interpretation, 3, no. 4, SAC99-SAC106, doi: 10.1190/INT-2015-0050.1.

Filina, I., and L. Hartford, 2019, Integrated analysis of seismic data and potential fields in Southeastern Gulf of Mexico with implications to pre-salt sediments and crustal architecture: AAPG Annual Convention and Exhibition, AAPG Datapages/Search and Discovery Article 90350.

Furlong, K. P., and D. S. Chapman, 2013, Heat flow, heat generation, and the thermal state of the lithosphere: Annual Review of Earth and Planetary Sciences, 41, 385-410, doi: 10.1146/annurev .earth.031208.100051.

Galloway, W., 2009, Gulf of Mexico: GEO ExPro, 6, https://www.geoexpro.com/articles/2009/03/gulfof-mexico.

Hales, A. L., C. E. Helsley, and J. B. Nation, 1970, Crustal structure study on Gulf Coast of Texas: AAPG Bulletin, 64, 2040-2057.

Hilterman, F., 1998, Rock property framework for comprehending deep-water seismic response: Presented at the 14th Annual Gulf Coast Technical Meeting, SEG.

Horn, B., A. Hartwig, J. Faw, I. Novianti, A. Goswami, and A. McGrail, 2017, Refining exploration opportunities in Mexico: GEOExPro, 14, 64-69.

Hudec, M. R., I. Norton, M. P. A. Jackson, and F. J. Peel, 2013, Jurassic evolution of the Gulf of Mexico salt basin: AAPG Bulletin, 97, 1683-1710, doi: 10.1306/04011312073.

Hunt, C. P., B. M. Moskowitz, and S. K. Banerjee, 1995, Magnetic properties of rocks and minerals, Classification of rocks and their abundances on the earth (3-1), 189-204.

Kneller, E. A., and C. A. Johnson, 2011, Plate kinematics of the Gulf of Mexico based on integrated observations from the Central and South Atlantic: Gulf Coast Association of Geological Societies Transactions, 61, 283-299.

Liu, M., 2018, Integrated geophysical analysis in the Northeastern Gulf of Mexico: M.S. thesis, The University of Nebraska-Lincoln. 
Liu, M., I. Filina, and P. Mann, 2019, Crustal structure of Mesozoic rifting in the Northeastern Gulf of Mexico from the integration of seismic and potential fields data: Interpretation, 2, no. 4, doi: 10.1190/int-2018-0259.1.

Lundin, E. R., 2017, The Gulf of Mexico and Canada Basin: Genetic siblings on either side of North America: GSA Today, 27, 4-11, doi: 10.1130/GSATG274A.1.

Mickus, K., R. J. Stern, G. R. Keller, and E. Y. Anthony, 2009, Potential field evidence for a volcanic rifted margin along the Texas Gulf Coast: Geology, 37, 387-390, doi: 10.1130/G25465A.1.

Nguyen, L. C., and P. Mann, 2016, Gravity and magnetic constraints on the Jurassic opening of the oceanic Gulf of Mexico and the location and tectonic history of the Western main transform fault along the eastern continental margin of Mexico: Interpretation, 4, no. 1, SC23-SC33, doi: 10.1190/ INT-2015-0110.1.

O'Reilly, C. O., J. Keay, A. Birch-Hawkins, D. Bate, and J. Halliday, 2017, Regional play types in the Mexican Offshore: GEO ExPro, 14, 36-45.

Pérez-Gussinyé, M., 2012, A tectonic model for hyperextension at magma-poor rifted margins: An example from the West Iberia-Newfoundland conjugate margins: Geological Society, London, Special Publications 369, SP369-19.

Pindell, J. L., and L. Kennan, 2001, Kinematic evolution of the Gulf of Mexico and Caribbean, transactions of the Gulf Coast section Society of Economic Paleontologists and Mineralogists: 21st Annual Bob F. Perkins Research Conference, Petroleum Systems of Deep-Water Basins, 2-5.

Pindell, J. L., C. E. Miranda, A. Cerón, and L. Hernandez, 2016, Aeromagnetic map constrains JurassicEarly cretaceous synrift, break up, and rotational seafloor spreading history in the Gulf of Mexico, in C. M. Lowery, J. W. Snedden, and N. C. Rosen, eds., Mesozoic of the Gulf Rim and beyond: New progress in science and exploration of the Gulf of Mexico Basin: SEPM Society for Sedimentary Geology 35.

Radovich, B., B. Horn, P. Nuttall, and A. McGrail, 2011, The only complete regional perspective: GeoExPro, 8, 36.

Rajmon, D., and V. Egorov, 2015, An overlooked petroleum system: Is it possible to generate hydrocarbons over the oceanic crust?: GeoExPro, 12, 12.

Sandwell, D. T., R. D. Muller, W. Smith, E. Garcia, and R. Francis, 2014, New global marine gravity model from CryoSat-2 and Jason-1 reveals buried tectonic structure: Science, 346, 65-67, doi: 10.1126/ science.1258213.

Saunders, A., L. Geiger, K. Rodrigues, and P. Hargreaves, 2016, The delineation of pre-salt license blocks in the deep offshore Campeche-Yucatan Basin: AAPG Annual Convention and Exhibition, Search and Discovery Article 10867.

Smith, W., and D. T. Sandwell, 1997, Global seafloor topography from satellite altimetry and ship depth soundings: Science, 277, 1957-1962.

Telford, W. M., L. P. Geldart, and R. E. Sheriff, 1990, Applied geophysics: Cambridge University Press.

Van Avendonk, H. J., G. L. Christeson, I. O. Norton, and D. R. Eddy, 2015, Continental rifting and sediment infill in the northwestern Gulf of Mexico: Geology, 43, 631-634, doi: 10.1130/G36798.1.

Whaley, J., 2006, Huge potential still waiting in the Gulf of Mexico: GeoExPro, 3, 14-24.

Williams-Rojas, C. T., E. Reyes-Tovar, L. Miranda-Peralta, G. Reyna-Martinez, A. Cardenas-Alvarado, R. Maldonado-Villalon, V. Muñoz-Bocanegra, and C. Lora-delaFuente, 2012, Hydrocarbon potential of the deepwater portion of "Salina del Istmo" province, southeastern Gulf of Mexico, Mexico: Gulf Coast Association of Geological Societies Transactions, 61, 681-684. 